\title{
Theoretical and practical, but rarely integrated: Norwegian primary school teachers' intentions and practices of teaching outside the classroom
}

\author{
$\varnothing_{\text {ystein Winje }}{ }^{1}$ (D) $\cdot$ Knut Løndal $^{1}$
}

Accepted: 21 May 2021 / Published online: 15 June 2021

(c) The Author(s) 2021

\begin{abstract}
This study investigates teachers' intentions and practices related to teaching outside the classroom. We report on three months of fieldwork consisting of participatory observations and qualitative interviews of teachers in two Norwegian primary schools practising weekly uteskole [outdoor school]. We find that the teachers' intentions for uteskole are to facilitate first-hand experiences for their pupils. The teachers organise and teach uteskole in two distinct ways: 1) friluftsliv activities [outdoor living activities] and 2) theoretical learning activities. The connections between friluftsliv activities and theoretical learning activities are seldom emphasised. Furthermore, the teachers rarely organise theoretical learning activities that entail pupils' transacting with their surroundings. We discuss how the teachers' work can be understood through the Romantic and the Pragmatist perspectives of experiential education and through the representational epistemology of traditional schooling. We outline how a transactional epistemology, operationalised as the "multi-modal model of knowing", can support teachers in facilitating transaction between the pupils and the environment outdoors and aid in establishing continuity between learning activities outdoors and indoors. We argue that these are important factors that can enhance uteskole as a teaching method for facilitating deep learning in Norwegian primary education.
\end{abstract}

Keywords Uteskole · Primary school - Teachers' intentions and practices . Epistemology $\cdot$ Friluftsliv

Øystein Winje

oywin@oslomet.no

Knut Løndal

knutlo@oslomet.no

1 Faculty of Education and International, 1 Studies, Department of Primary and Secondary

Teacher Education, Oslo Metropolitan University, Oslo, Norway 


\section{Introduction}

The aims of this study are to investigate Norwegian teachers' intentions for uteskole [outdoor school] and to explore how they practise this way of teaching.

According to Jordet (2010), uteskole is defined as regular classes held outside the school buildings on a weekly or bi-weekly basis in natural (e.g., forests and beaches) or cultural contexts (e.g., museums, theatres and farms) in order to enhance the pupils' understanding of a given subject. In Scandinavian countries, a grassroots movement of teachers have integrated uteskole into their teaching methods. The method has been described as initiating inquiry-based, problem-solving activities with explorative and practical approaches and is mainly practised in primary school (Barfod et al., 2016). The aspects of teaching and learning highlighted above are reflected in a central term in the current educational discourse: 'deep learning'. According to the Organisation for Economic Co-operation and Development (OECD) report "The Nature of Learning" (Dumont et al., 2010), the United States National Research Council report "Education for Life and Work" (Pellegrino \& Hilton, 2012), and the recent curriculum reform in Norway (The Norwegian Directorate for Education \& Training, 2020), deep learning entails that pupils seek to understand the meaning of the teaching materials, relate their ideas to their previous knowledge and experiences, and transfer and utilise their skills and knowledge in novel contexts. Dahl and Østern (2019) argue that all aspects of learning, i.e., embodied, social, emotional and cognitive, should be incorporated in teaching practices meant to facilitate deep learning. However, deep learning has mainly been investigated as a cognitive phenomenon (Winje \& Løndal, 2020).

In Norway, the governmental authorities establish principles, values and competency aims for each subject in the school system, while the local municipalities and school leaders determine how they are achieved (Mølstad et al., 2020). The classroom setting is the most dominant context for teaching and use of environments outside has been limited to sporadic trips and excursions (Jordet, 2010). However, as Waite et al. (2016) describe, the Scandinavian countries have traditionally been associated with a strong cultural affiliation with nature, enjoying the outdoors and promoting cultural heritage and national identity, which can be summarised in the term friluftsliv. Lyngstad and Sæther (2020) highlight that outdoor recreation, outdoor life, free-air-life and adventure are concepts that can all be related to friluftsliv. Friluftsliv has been part of the Norwegian curriculum for over 40 years, and in their systematic literature review of friluftsliv in Norwegian primary and secondary education, Abelsen and Leirhaug (2017) found that seven of the twenty-four included studies were related to uteskole, indicating that friluftsliv is a central theme in the practice of uteskole. In Norway, the choice of teaching method is the responsibility of the teachers who traditionally have autonomy in their choice of methods. The pedagogical ideas and didactic methods of uteskole are incorporated in some courses of teacher education, often as part of specialisations in physical education or science, but there are no certification requirements for practising uteskole in Norway.

International reviews of outdoor learning programmes have found that regular compulsory school- and curriculum-based programmes can promote pupils' 
development in social, academic, physical and psychological dimensions (Becker et al., 2017; Rickinson et al., 2004). According to Guardino et al. (2019), classes held outdoors provide a more authentic and engaging environment as well as opportunities to integrate content area subjects within outdoor experiences. Knowledge and practices related to uteskole, recently furthered by the Danish TEACHOUT project, document an increase in pupils' physical activity (Schneller et al., 2017), school motivation (Bølling et al., 2019) and enhancement of academic skills (Otte et al., 2019). Studies report that integrating outdoor learning programmes may be challenging due to lack of support from the school administration and colleagues, limited resources, limited time, and risk management (Bentsen et al., 2010; Rickinson et al., 2004). Barfod (2018) highlights that most research on uteskole has focused on pupils' learning outcomes, whereas few studies have investigated teachers' lived experiences of teaching outside the classroom. The lack of research indicates a need for studies investigating teachers' experiences with teaching outside the classroom. The aim of this study is to investigate teachers' intentions and practices related to uteskole, guided by the following research questions:

- What are teachers' intentions in practising regular uteskole?

- What activities and strategies do teachers utilise when practising uteskole?

When approaching this study, our expectations, primarily based on our own experience practising uteskole and working in teacher education, were that the teachers would emphasise teaching friluftsliv in uteskole to make their pupils enjoy being outdoors. Several theoretical perspectives might contribute to the understanding of teachers' work with uteskole.

\section{Theoretical perspective}

Uteskole is part of the field of experiential education, encompassing a variety of curriculum projects from outdoor and environmental education to service learning and place-based education, drawing from the same progressive intellectual taproot, the belief in the educational power of experience. Roberts (2012) elaborates on the theoretical perspectives of experiential education and identifies four "currents": Romantic, Pragmatist, Critical Theory and Market Rationality. This analysis have been used in research on outdoor education, for example, by Mannion and Lynch (2016) focusing on "place" in education, and Warner et al. (2020) regarding the emergence of neoliberal ideologies in outdoor adventure education. However, we have not been able to identify any research applying Roberts' analysis to uteskole, and we believe that this could be a useful framework to guide our understanding of uteskole teachers' intentions and practice. We decided to focus on the Romantic and the Pragmatist perspectives because they purport different viewpoints on knowledge and learning.

According to Roberts (2012), a Romantic perspective entails that the central aim of education is 'to provide opportunities to learn from experience before learning 
from labels' (p. 39). Labels or representations are mediated by society, while experiences emerge from the unmediated contact between the individual and the environment. The philosophical foundations for this perspective can be found in Rousseau's notions of an ideal educational process focusing on the free and natural development of the individual, avoiding the corrupting influences of society. As Rorty (1998, p. 248) explains, 'He is to learn from experience, by the consequences of his actions rather that from persons or books'. Roberts (2012) argue that teaching practices based on a Romantic perspective of experience and learning represent a significant limitation in curriculum-based education. The Romantic perspective also extends to the understanding of friluftsliv in Nordic educational research. Goga et al. (2018, p. 12) characterise one of the main elements in their Nature in Culture Matrix as the celebratory position, which "implies the idea of the "pure child" or "child in nature" as a key figure in the cultural and pedagogical position.

According to Roberts (2012), the central aim of education, seen from a Pragmatist perspective, is to facilitate curriculum projects, with knowledge being shared and used to solve problems in authentic situations. The Pragmatist perspective highlights a conscious connection between the school and the community. The notions of experience and education of Pragmatist philosopher John Dewey are often described as fundamental to experiential education (Ord \& Leather, 2011; Quay \& Seaman, 2013), especially his critique of the dichotomy between 'the school world' and 'the real world", the dialectic relationship between "action" and "reflection", and the importance of context in acquisition of skills and knowledge.

Dewey (1963) underlines two criteria for educational experiences, continuity and interaction. Continuity means that every new experience incorporates elements from previous experiences and modifies the quality of later experiences. A consequence of the principle of continuity is that education should be defined as 'the reconstruction or reorganisation of experience which adds to the meaning of experience, and which increases ability to direct the course of subsequent experience' (Dewey, 1916, p. 16). Interaction refers to the interchange that occurs between the internal conditions of the subject and the objective conditions of the environment; these two aspects form a situation. Accordingly, the duty of the educator is to "determine that environment which will interact with the existing capacities and needs of those taught to create a worth-while experience' (Dewey, 1963, p. 45). In later writings, Dewey preferred the term 'transaction' rather than 'interaction' because transaction emphasises the process, while interaction suggests the existence of independent entities that interact (Dewey \& Bentley, 1949). We agree with Deweys' nuancing of the term and, similar to Biesta and Burbules (2003), use "transaction" as the preferred term in this article.

Several scholars within the field of experiential education argue that Dewey's theories have been misunderstood or simplified. Roberts (2012) describes how the catchphrase "learning by doing" seems to be equated with a method. Quay and Seaman (2013) and Ord and Leather (2011) both argue that Deweys' theories have become overly simplified within the field of outdoor education, and there has been little emphasis on the dialectic relationship between "action" and "reflection". Although Dewey's theories are purported as fundamental to experiential education, it seems researchers and practitioners in the field struggle with how his theories can 
be implemented in practice. Nicol (2003) suggests that Western philosophy's focus on dualistic thinking and the epistemological understanding of knowledge as a second-order expression of reality might affect outdoor educators' practice.

\section{Representational epistemology}

Biesta and Burbules (2003, p. 9) describe the traditional understanding of epistemology as "the branch of philosophy that tries to give an answer to how our mind can acquire knowledge of a world outside our mind". Until the late nineteenth century, new generations mainly learned through participation in everyday work, but as Osberg et al. (2008) pinpoint, when traditional schooling was established, school became a separate educational world for children needing to represent "real life" within the confines of school, and this is achieved through the use of "representations", a second-order expression of reality. Biesta and Burbules (2003) refer to this understanding of knowledge as a representational epistemology; what is presented in education stands for something else that is 'out there'. They suggest that a representational epistemology might be understood as an original and inevitable distinction that is given for all philosophies and found in the dualistic distinctions between mind and matter, subject and object, and mental and physical. For Dewey (1925), there is no dualistic point of entry; the only way we can understand these processes is through our activities - the "doings" - and experiencing their consequences. Nicol (2003) argues that sometimes it is appropriate that knowledge is represented in this way; however, it becomes a problem if it is monopolised, resulting in society favouring one form of knowing over others. He claims that the representational epistemology is a historically inherited epistemological position that has become a deeply embedded cultural construct acting as an invisible mediator of knowledge that affects and shapes current teaching practices.

According to Biesta and Burbules (2003), Dewey argues that the dualistic perspective, which representational epistemology is founded upon, is flawed because it tends to centre on the mind and cognitive aspects rather than the interactions between the human organism and its environment. Dewey (1925) rejected the Cartesian mind-body dualism and instead claimed that 'higher' cognitive operations occur against the background of a complex interplay between the individual and the environment, suggesting that there is no division between the act and material of the subject; rather, both are contained in an unanalysed totality.

\section{Transactional approach and transactional epistemology}

To overcome what he describes as a false division between the human organism and the environment, Dewey (1925) proposes the use of the empirical method. When we encounter a problem, what he calls a primary experience, we can perform symbolic actions - an activity he calls 'thinking' where we try different lines of action without being subjected to the consequences. However, it is only when we act that we can know if our action was appropriate. Thus, the result of 'thinking' is a secondary experience that needs to be tested against the problem first encountered. Dewey 
calls this the transactional approach in a later work (Dewey \& Bentley, 1949). He argued that experiences are always intertwined and that making distinctions between primary and secondary experiences should be regarded as a tool for analytical purposes. Ord and Leather (2011, p. 15) find it useful to look at experiential learning from a three-dimensional stance, "as a continuing spiral of action designed to build upon each other and so extend an individual's range of experience and cognition over time".

Building on Dewey's transactional approach, Biesta (2010) questions the representational epistemology and suggests an alternative perspective, a transactional epistemology, where we must concede that the knowledge we gain through experimentation is knowledge about the relationships between actions and consequences that may provide us with hypotheses for problem solving, although there will always be a gap between our knowledge and new situations. There is no guarantee that what was possible in the past will also happen in the future. Biesta argues that we must give up the idea that it is possible to achieve complete knowledge about reality because the world always appears to us through our actions, and subsequently, the world always changes as a result of our actions: we are participants in an everevolving universe. As Ord and Leather (2011) pinpoint, the notion of "change" is as a reconceptualisation of how we see the world as much as an actual physical change in it. Thus, when we experience, we are changed, but so is the world, both how we perceive and conceive it as changed.

\section{Epistemology in outdoor education and uteskole}

Dewey's transactional approach, comprising a positive circular process of primary and secondary experiences processed through 'thinking', is integrated in the didactic model of uteskole in the works of Jordet (2010). The uteskole context provides opportunities for pupils to have primary experiences outside school, while the classroom is a suitable context for performing symbolic actions. Uteskole is suitable for testing these different lines of action outside the classroom, and pupils can be subjected to the reality of consequences that may be reflected and elaborated in a continuous positive circular process.

The representational epistemology and the transactional epistemology seem to coexist in the field of experiential education, and Nicol (2003) highlights the need for outdoor educators to be familiar with different epistemological positions and adopt an epistemological strategy that is appropriate for the learning outcomes they are trying to achieve.

\section{Materials and methods}

In the present study of teachers' intentions and practices, we chose to conduct a multiple case study (Yin, 2008) in two primary schools with regular uteskole in Norway. Since we aimed to explore teachers' intentions and practice, we wanted to study the subjects in real-life situations and adopted a qualitative life-world approach 
(Bengtsson, 2006). Data collection included participatory observations over a period of three months followed by qualitative research interviews with the teachers.

\section{Sample}

The prevalence of uteskole in Norway has not recently been mapped, and we used snowball sampling (Cohen \& Arieli, 2011), utilising our network of teachers, principals and educational researchers to identify relevant schools. The main inclusion criterion was that the schools themselves highlighted and promoted uteskole as a weekly feature. Two schools were selected, both located in the eastern part of Norway. School 1 (S1) is a primary school with 400 pupils between 6 and 13 years of age with lower socio-economic background situated in a suburban neighbourhood near a forest. Each grade has two classes, each consisting of 20-25 pupils. Only first and second grades have uteskole weekly in this school, and we decided to include the pupils in the second grade and the two teachers who always participated in uteskole. School 2 (S2) is a primary and lower secondary school with 600 pupils between 6 and 16 years of age from higher socio-economic backgrounds, situated in a suburban area. Each grade has two classes consisting of approximately 25 pupils. Fifth to seventh grades have uteskole weekly, and the three teachers who always participated in uteskole were included. The teachers are given aliases that accurately represent their genders, and their school affiliation is denoted by adding S1 or S2 after their names. Three of the teachers, Annie (S1), Lawrence (S2) and Otto (S2), had been practising uteskole for many years, while two of the teachers, George (S1) and Charlie (S2), had been practising it for only a few years.

\section{Data collection}

The fieldwork was completed in the autumn of 2018 with participatory observations for a total of 15 days. As recommended by Brinkmann and Kvale (2015), the structure and themes of the observation guide were refined through preliminary visits during a uteskole day at each of the two schools. At S1, the teachers were observed for six whole days that included a combination of outdoor and classroom activities. At S2, the teachers were observed for six whole outdoor days and three short days with classroom activities related to the uteskole because, in contrast to S1, these activities are not carried out the same day as the outdoor days. Notes on activities were recorded continuously without predetermined activity categories. In line with Merriam (2009), the group was followed during their regular routines, and field notes were taken of the teacher's activities and locations. Information was collected from teachers through walk-along interviews and conversations, and the field notes were rewritten into complete text files within two days. After the observation period, a comfortable setting (staff room, at home) were used for individual interviews of the five teachers. As suggested by Brinkmann and Kvale (2015), a semi-structured interview guide with open-ended and explorative questions was tested through a pilot interview with a colleague who had extensive experience with uteskole, leading to a 
revision of questions with overlapping themes. The interviews were audio-recorded and lasted between 45 and $120 \mathrm{~min}$.

\section{Transcription and analysis}

The first author prepared the field notes, and a professional transcriber wrote the interviews verbatim. The interview transcripts were checked against the audio files by the first author to ensure that the meanings had been captured (Brinkmann \& Kvale, 2015).

The analyses were inspired by the six-step model of thematic analyses of Braun et al. (2016). In the first phase, the material from the observations and the interviews were read several times with increasing thoroughness to obtain an overview. In the second phase, codes were developed to clarify and structure the material. In phases 3 to 5 , codes were further developed, improved and named. In the sixth and final phase, the findings were structured and written into the research report. This sixstep model for analysis should be considered a dynamic process that is continually shaped by the researcher's active choices (Braun et al., 2016).

In line with Braun and Clarke (2006), the inductive interpretation of the identified themes was strongly linked to the data, while the theoretical interpretation was supported by relevant theory. As suggested by Braun et al. (2016), inductive interpretations were performed first, and theoretical interpretation was conducted later with the use of theory to highlight and support the inductive interpretations.

\section{Trustworthiness}

As described by Merriam (2009), we provided thorough descriptions of all steps in the research process, referred to the field notes and interview transcriptions during presentation of the results, and related them to theories, methods, and concepts used in previous studies on uteskole, outdoor learning and experiential education. As suggested by Johnson (1997), both authors initiated and planned for the study, the first author conducted the fieldwork and the interviews, and both authors collaborated discussing the data collection and participated actively in the analyses, also focusing on discovery and inclusion of situations and interpretations that did not conform to our expectations, as described in the introduction section.

\section{Ethical considerations}

The teachers, pupils and pupils' guardians were given oral and written information about the project, the possible consequences of participating and their ability to withdraw at any time before they gave written consent upon participation (Brinkmann \& Kvale, 2015). As suggested by Backe-Hansen and Frønes (2012), when following particular pupils during observation, the first author always asked them for permission before doing so. To secure confidentiality, all informants were given aliases, no characteristics regarding the participants' appearance or ethnic background were recorded, and the schools' names are not reported. The Norwegian Centre for 
Research Data approved the steps taken in this project to protect the participants' privacy (Project Number 60432). All extracts from interviews are reproduced in the author's translation, as loyal to the spoken language as possible; however, the participants were not given the opportunity to member check their data after the translation.

\section{Results}

When presenting the results on the teachers' intentions and practices related to uteskole, we refer to situations that represent the totality of the material. Information on the teachers' intentions is mainly found in the interview data, whereas information on the teachers' practices, activities and strategies regarding uteskole is mainly found in the observation and interview data. The two data sets reveal three main themes related to the research questions:

First-hand experiences (1) comprise teachers' intentions to use uteskole to provide the pupils with experiences of what they call 'real life', to help the pupils process these experiences, and the barriers they face when trying to do so. Friluftsliv activities (2) and theoretical learning activities (3) describe the two main strategies used in practising uteskole.

\section{First-hand experiences}

The teachers in both schools describe that their main intention for uteskole is to provide opportunities to gain first-hand experiences in what the teachers call 'real life'. As Annie (S1) explains,

I believe that the most important part is the relation to real-life and first-hand experiences. It is not just something they are going to sit and read about; they can touch things, smell them and get a feel for them.

The teachers emphasise that leaving the classroom and bringing the pupils into "real life" outside enhances their learning because it connects school and curriculum to authentic environments. They also highlight the pupils' opportunities to use all their senses in uteskole, to strengthen experiences stimulating long-term memory.

Although the teachers express similar intentions regarding first-hand experiences, they express different views regarding processing of experiences in uteskole. George and Annie (S1) emphasise the importance of a close connection between learning activities in the classroom and in uteskole. As George (S1) describes,

You can sit in a classroom and learn about birds by watching movies or drawing. However, the idea is to do it inside first and then go out and watch and listen to the birds. Unfortunately, they cannot touch the bird, but they are not far from it; they are studying it. Then, we return to the classroom, and they can capture their experience on a piece of paper. In this way, they enhance their learning. 
George and Annie envision a positive circular learning process between uteskole and the classroom by working with the material theoretically in the classroom and more experientially in uteskole. The teachers in S2 focus on providing opportunities for the pupils to experience nature and to be physically active. Otto, Lawrence and Charlie (S2) describe an indirect processing of first-hand experiences where the first-hand experiences from uteskole are understood as something that the teacher might highlight or draw parallels to at a different time.

\section{Barriers regarding the processing of first-hand experiences}

Although teachers from both schools highlight the potential of processing first-hand experiences, they also describe certain obstacles. Annie and George (S1) mention their frustration with lack of time resources for planning and for teacher collaboration when practising uteskole. The teachers in S2 also express challenges with facilitating processing first-hand experiences, as Lawrence explains: 'No, we are not that structured. The fact that we have three different age groups makes it difficult to connect to the classroom activities". When pupils from three grade levels attend at the same time, it is too burdensome to cooperate with other teachers with different subjects in their respective classes. The teachers in S2 acknowledge that facilitating a structured processing of first-hand experiences might also enhance the pupils' learning of curriculum content, but they do not schedule or organise a collective reflection.

Although the teachers express somewhat different intentions and encountering different challenges in their uteskole practices, they utilise the same two main activities of friluftsliv and theoretical learning.

\section{Teachers' practices - Friluftsliv activities [outdoor living activities]}

All our informants highlight that uteskole provides possibilities for teaching skills relevant to being outdoors and participating in Norwegian culture. A typical description is given by Annie (S1):

Uteskole is the main arena for teaching friluftsliv. When we think about skiing, skating, hiking and bonfires, it is not something every Norwegian does regularly, but it is an important part of our culture that can be passed on to all the kids with a completely different culture in a natural way, which they do not necessarily encounter elsewhere.

In addition to explaining uteskole as a way to teach about appropriate outdoor clothing and general outdoor skills, the teachers describe uteskole as a natural way of teaching friluftsliv to pupils with a different cultural background, making them more prone to seek similar experiences in the future.

The teachers all emphasise the positive aspects of friluftsliv activities in uteskole, but some teachers also note that they are not always able to carry out the intended theoretical learning activities because it takes longer than anticipated to travel to the uteskole location. 


\section{Teachers' strategies - Theoretical learning activities}

While the previous two themes present findings derived mainly through inductive analysis, the findings in this theme were established mainly through thematic and theory-driven analysis. We identified two underlying strategies regarding the facilitation of theoretical learning activities: manipulation of symbols (1) and the connection between theoretical and practical learning activities (2).

\section{Manipulation of symbols}

The pupils' ability to manipulate and represent symbols plays a significant part in both schools' uteskole activities, and the products are mainly symbolic representations, i.e., words, calculations or drawings, exemplified by an observation from S2:

Charlie takes 20 pupils away from the main group at the campsite to an open area. He lets the pupils choose who they want to pair up with and presents a piece of paper with four rebuses that reveal the names of four Norwegian inventions.

This observation note exemplifies the emphasis on representations and theoretical learning in the uteskole context, where the pupils need to combine drawings, numbers and letters.

Combining physical activity and repetition of theoretical knowledge is also a typical activity in both schools, as Annie (S1) describes:

We use a task called 'The 50-game', where they (the pupils) solve fifty different repetition tasks related to content they have been taught in, for example, religion, math or science. They run around looking for task sheets that are spread over a limited area in the woods; they solve the tasks and return to us with the answers.

The teachers combine physical activity and the repetition of content that the pupils have worked on in the classroom before, often through quiz-like tasks. In uteskole, the pupils either have freedom of movement or are required to perform some sort of physical activity while solving these tasks.

\section{The connection between theoretical and practical learning activities}

The teachers organise learning activities aiming to integrate and apply knowledge attained in the classroom to authentic situations outdoors. The following observation notes from $\mathrm{S} 2$ provide an example:

The pupils are divided into groups of two to four and given a map which they shall use to find their way to a forest located some distance from the school. Otto, Lawrence and Charlie follow at some distance, either by foot or by bike. If one of the groups diverges from the route laid out on the map, the teachers' guide them in the right direction. Since the teachers walk behind the pupils 
during the activity, there is little probability of any of the groups not finding the uteskole location; however, one group still manages to get lost, and the teacher has to guide the pupils to the correct location. The pupils stop at designated spots on the map to solve math tasks. A typical task is as follows: "At this address, there is a house. Count the number of windows, divide by the number of outdoor lights, and add the number of garages. What is the answer?'

The task consists of several steps: the pupils must 1) find the correct address, 2) gather information about elements of the house or garden, and then finally 3) perform calculations and write the answers on a piece of paper. At the end of the uteskole day, the teachers evaluate the pupils' efforts by checking their answers. However, the practical use of the map is not emphasised by the teachers other than an expression of slight frustration regarding the one group becoming lost.

Another example of an activity aimed to establish connection between theory and practice is observed in S1. Before going out, the teacher explains how to build a bonfire and how to behave safely, but when it is time to build the bonfire, the pupils are given a totally unrelated task to create land-art that must contain either letters or numbers. The practical steps of finding firewood and building, lighting and putting out the bonfire are performed by the teacher without any of the pupils participating. When they return to the classroom, the pupils are tasked with processing their experiences in uteskole by reading, writing and colouring a template about bonfires. These learning activities are mainly theoretical: 1) learn the rules and principles of bonfires in the classroom before going out, 2) use symbols to create land art at the uteskole location, and 3) read the principles of bonfires and colour a template of children sitting around a bonfire when back in the classroom.

We find that the teachers intend to use uteskole to facilitate situations where the pupils can experience "real life" and that, ideally, these experiences are processed through reflection, conversation, writing and drawing. However, the teachers find it challenging to facilitate this processing due to limited time in planning and coordinating with the other teachers and the tight scheduling of school days. The teachers intend to focus on both friluftsliv activities and theoretical learning activities in uteskole, but they are not integrated with each other.

\section{Discussion}

Our research questions - What are teachers' intentions in practising regular uteskole, and what activities and strategies do teachers utilise when practising uteskole? - present the following issues for discussion.

\section{Romantic and Pragmatist intentions}

The teachers from both schools' express intentions in their uteskole practice and organise activities, reflecting elements of both the Romantic and Pragmatist currents in the field of experiential education despite their quite different positions regarding education. 


\section{Romantic}

The teachers emphasise facilitating situations in uteskole where the pupils can experience nature first-hand, particularly friluftsliv activities, such as walking, hiking, skiing or bicycling to the uteskole location, different camp activities involving bonfires, the use of saws, axes and knives, and playing in nature. The teachers describe these activities as educative and argue that they are important because friluftsliv is a central part of both the physical education (PE) curriculum and Norwegian culture. This is in line with Lyngstad and Sæther (2020, p. 11) claim that the pupils do not only learn to master skills related to friluftsliv but also about themselves as "subjects in nature". The teachers' statements that these friluftsliv activities are educative in themselves and the lack of emphasis on establishing a connection between these activities and learning activities in the classroom or theoretical knowledge might be interpreted as expressions of a Romantic perspective. This Romantic notion of friluftsliv is also described in Nordic educational research, for example, by Goga et al. (2018) calling it the "celebratory position", and similar accentuation of friluftsliv can be found in the new Norwegian curriculum (The Norwegian Directorate for Education \& Training, 2020).

Roberts (2012) underlines that from a Romantic perspective, the idea of the transformative potential in direct experiences can be disrupted by too much structure and discipline. The importance of avoiding the corrupting influences of society purports an educational practice where the individual stands alone, destined to make sense of experiences solely through their own previous experience, an individualisation of the educational process. Dewey (1963, p. 25) warned "the belief that all genuine education comes about through experience does not mean that all experiences are genuinely or equally educative. Experience and education cannot be directly equated to each other". Even though the pupils' first-hand experiences in uteskole may be powerful and lead to formative changes, the individual emphasis on the Romantic current makes it difficult to incorporate it into curriculum programmes. Furthermore, the disregard of society and its "corruptive influence" on pupils' does not blend well with the idea of education as a tool for developing future democratic citizens. Our findings indicate that one might miss opportunities to actualise the pupils' experiences into useful educative processes when relying on the idea that the experiences are formative enough in themselves.

\section{Pragmatist}

The teachers in this study also express intentions and practices in line with a Pragmatist position. The teachers from S1 explicitly adhere to the didactic model of uteskole (Jordet, 2010) by intending to establish a connection between learning activities in the classroom and learning activities in uteskole through a positive circular learning process. This could fulfil one of Dewey (1963) criteria for educative experience, as an example of continuity. However, the main emphasis of the teachers in S1 seems to be on documenting the pupil's experiences by representing it afterwards, in the classroom. This seems to be based on an understanding influenced by traditional ideas of schooling and a representational epistemology. This 
interpretation of the teachers understanding is further strengthened when we look at the learning activities that are organised outdoors. In addition to the friluftsliv activities, the teachers organise theoretical learning activities, which involve the repetition of previously taught curriculum content, letters, numbers, and calculus. This highlights a paradox: representational knowledge, which is used to represent the world outside the classroom, is brought outside, into the context that it is meant to represent. Instead of facilitating activities through which the pupils are able to utilise and test their knowledge in authentic situations, what (Dewey, 1963) would call transactions, they are given representational learning tasks identical to those given in the classroom. This is a potent example of how a representational epistemology permeates teachers' practices and becomes the main focus of uteskole. The incorporation of physical activity, e.g., the "50 s game" of running combined with solving quiz-questions seems to be an attempt by the teachers to establish a transaction between the pupils and the environment, but without connection between the physical activity and the theoretical learning activity. The Active Smarter Kids (ASK) project (Resaland et al., 2016) examined a suggested connection between physical activity and academic achievement but could not document significant associations. The emphasis on documentation and representational knowledge and the lack of focus on facilitating transactions between the pupils and their surroundings result in a distortion of the didactic model of uteskole and lead to practices that cannot be considered in line with Dewey (1963) notions of experience and learning. As Murphy (2020, p. 1) highlights, teachers teaching outside the classroom should set up an environment that invites and sustains active investigation and that "the outdoor learning environment should not mirror the indoor classroom or the school yard at break time".

\section{Epistemology and structure}

According to Ord and Leather (2011), similar simplifications or misunderstandings of Dewey's theories are common in the field of outdoor education. They argue that "reflection after action" simply is not enough because an experience and the resulting learning is established as a continuous transaction. The teachers bring the representations and indoor learning activities outdoors in an attempt to establish continuity. Unfortunately, this creates a disruptive effect; the focus is moved away from pupils transacting with their surroundings to pupils transacting with representations, which are seldom related to the context, e.g., a rebus with Norwegian inventors.

The teachers express several barriers that limit their efforts and fuel frustrations, such as lack of time resources, coordination and support, as reported in studies of uteskole (Bentsen et al., 2010) and studies of outdoor education (Rickinson et al., 2004). Nicol (2003) argues that educational institutions have become preoccupied with separating and compartmentalising knowledge. The rigid emphasis on timetabling, 45-min classes, 15-min breaks, and strict differentiations of school subjects results in schools mirroring the organisation of production lines, which might make it difficult to facilitate learning situations where the pupils can experience how school subjects are interconnected and related to anything beyond the classroom. 
Although the Pragmatist foundation of uteskole is reported as important by the teachers, the struggle in uteskole seems to be both epistemological and structural.

\section{"Multi-modal model of knowing" as an operationalisation of a transactional epistemology}

One way of helping teachers liberate themselves from the grip of representational epistemology might be as Nicol (2003) outlines in the concept of a "multi-modal model of knowing", providing an alternative framework of epistemological diversity. He distinguishes between experiential, presentational, propositional and practical ways of knowing. Experiential knowing is knowing through the direct first-hand experience of a person, place or thing. Presentational knowing is manifest in images that articulate experiential knowing, for example: arts, music, dance, poetry and drama. Propositional knowing is knowing "about" something in intellectual terms of ideas and theories and expressed in abstract language or mathematics. Practical knowing involves how to do something, expressed as a skill, knack or competence. This "multi-modal model of knowing" may be an important guide to operationalise a transactional epistemology into the practice of uteskole.

In Norway, the recent curriculum reform highlights deep learning, which entails ensuring that pupils seek to understand the meaning of the teaching materials, relate their ideas to their previous knowledge and experiences, and transfer and utilise their skills and knowledge in a novel context (The Norwegian Directorate for Education \& Training, 2020). We argue that uteskole is a teaching method that may support teachers in facilitating deep learning.

There is a need for increased focus on the integration of both theoretical and practical learning activities in uteskole. The teachers should adopt an epistemological position that entails a holistic understanding of knowing, in which all aspects of learning are incorporated in the teaching practices and such an integration presupposes a transactional epistemology as the foundation. This is an epistemological position that is congruent with the philosophical foundations of uteskole and Deweys' perspective on experience, learning and education. A transactional epistemology, operationalised through a "multi-modal model of knowing", can provide support to teachers in order to facilitate transaction between the pupils and the environment outdoors, ultimately aiding them in establishing continuity between learning activities outdoors and indoors.

\section{Concluding remarks}

The teachers' serious intentions to facilitate first-hand experiences of the environment outside the classroom to enhance their pupils' learning encounter difficulties in linking experiences in uteskole with the curriculum content. The teachers' frustrations are related to the lack of all types of resources, but the multiple epistemologies that are embedded in and influence their practices seem to be the main obstacles to taking advantage of the possibilities in the didactic model of uteskole. Furthermore, 
we find that the Romantic and Pragmatist currents, which entail very different notions of how learning should be facilitated, are both present in the teachers' intentions and practice of uteskole. The emphasis on the transformative power of direct experience in the Romantic current is mainly reflected in the teachers focus on friluftsliv, while the Pragmatist emphasis on processing experiences is reflected in the focus on documenting the first-hand experiences and the attempts to facilitate continuity and transaction through theoretical learning activities outdoors. For uteskole to more consistently contribute to Norwegian schools' commitment to deep learning, teacher training programmes should focus on learning about the different epistemological positions and how these positions might influence the practice of uteskole. There is a need for further studies of teachers' intentions and practices related to uteskole that critically apply its foundational philosophical framework.

Authors' contributions $\varnothing \mathrm{W}$ designed the study, carried out the fieldwork, analysed the data and wrote the manuscript; KL designed the study; analysed the data and wrote the manuscript.

Funding Open access funding provided by OsloMet - Oslo Metropolitan University.

Data availability Not applicable.

Code availability Not applicable.

\section{Declarations}

Conflict of interest The authors have no relevant financial or non-financial interests to disclose.

Open Access This article is licensed under a Creative Commons Attribution 4.0 International License, which permits use, sharing, adaptation, distribution and reproduction in any medium or format, as long as you give appropriate credit to the original author(s) and the source, provide a link to the Creative Commons licence, and indicate if changes were made. The images or other third party material in this article are included in the article's Creative Commons licence, unless indicated otherwise in a credit line to the material. If material is not included in the article's Creative Commons licence and your intended use is not permitted by statutory regulation or exceeds the permitted use, you will need to obtain permission directly from the copyright holder. To view a copy of this licence, visit http://creativecommons.org/licen ses/by/4.0/.

\section{References}

Abelsen, K., \& Leirhaug, P. E. (2017). Hva vet vi (ikke) om elevers opplevelser med friluftsliv i norsk skole: En gjennomgang av empiriske studier 1974-2014. Journal for Research in Arts and Sports Education, 1(3), 47-60. https://doi.org/10.23865/jased.v1.615

Backe-Hansen, E., \& Frønes, I. (2012). Metoder og perspektiver i barne- og ungdomsforskning. Gyldendal.

Barfod, K. (2018). Maintaining mastery but feeling professionally isolated: Experienced teachers' perceptions of teaching outside the classroom. Journal of Adventure Education and Outdoor Learning, 18(3), 201-213. https://doi.org/10.1080/14729679.2017.1409643

Barfod, K., Ejbye-Ernst, N., Mygind, L., \& Bentsen, P. (2016). Increased provision of udeskole in Danish schools: An updated national population survey. Urban Forestry \& Urban Greening, 20, 277-281. https://doi.org/10.1016/j.ufug.2016.09.012 
Becker, C., Lauterbach, G., Spengler, S., Dettweiler, U., \& Mess, F. (2017). Effects of regular classes in outdoor education settings: A systematic review on students' learning, social and health dimensions. International Journal of Environmental Research and Public Health, 14(5), 485. https://doi.org/10. 3390/ijerph14050485

Bengtsson, J. (2006). En livsverdenstilnærming for helsevitenskapelig forskning. In J. Bengtsson (Ed.), А forske $i$ sykdoms-og pleieerfaringer Livsverdensfenomenologiske bidrag (pp. 13-58). Høgskoleforlaget.

Bentsen, P., Søndergaard Jensen, F., Mygind, E., \& Barfoed Randrup, T. (2010). The extent and dissemination of udeskole in Danish schools. Urban Forestry \& Urban Greening, 9(3), 235-243. https:// doi.org/10.1016/j.ufug.2010.02.001

Biesta, G. (2010). Why "what works" still won't work: From evidence-based education to value-based education. Studies in Philosophy and Education, 29, 491-503. https://doi.org/10.1007/s11217-010-9191-x

Biesta, G., \& Burbules, N. (2003). Pragmatism and educational research. Rowman \& Littlefield Publishers Inc.

Braun, V., \& Clarke, V. (2006). Using thematic analysis in psychology. Qualitative Research in Psychology, 3(2), 77-101. https://doi.org/10.1191/1478088706qp063oa

Braun, V., Clarke, V., \& Weate, P. (2016). Using thematic analysis in sport and exercise research. In B. Smith (Ed.), Routledge handbook of qualitiative reseach in sport and exercise (p. 15). Routledge.

Brinkmann, S., \& Kvale, S. (2015). InterViews: Learning the craft of qualitative research interviewing. Sage.

Bølling, M., Niclasen, J., Bentsen, P., \& Nielsen, G. (2019). Association of education outside the classroom and pupils' psychosocial well-being: Results from a school year implementation. Journal of School Health, 89(3), 210-218. https://doi.org/10.1111/josh.12730

Cohen, N., \& Arieli, T. (2011). Field research in conflict environments: Methodological challenges and snowball sampling. Journal of Peace Research, 48(4), 423-435. https://doi.org/10.1177/0022343311405698

Dahl, T., \& Østern, T. P. (2019). Dybde//læring med overflate og dybde. In T. P. Østern, T. Dahl, A. Strømme, J. A. Petersen, A. L. Østern, \& S. Selander (Eds.), Dybde//lacring (pp. 39-56). Universitetsforlaget.

Dewey, J. (1916). Democracy and Education. The Echo Library.

Dewey, J. (1925). Experience and Nature. Dover Publications.

Dewey, J. (1963). Experience and education. Collier-Macmillan.

Dewey, J., \& Bentley, A. F. (1949). Knowing and the known. Southern Illinois University Press.

Dumont, H., Instance, D., \& Benavides, F. (2010). The Nature of Learning: Using Research to Inspire Practice, Educational Research and Innovation.

Goga, N., Guanio-Uluru, L., Hallås, B. O., \& Nyrnes, A. (2018). Ecocritical perspectives on children's texts and cultures: Nordic dialogues. Palgrave Macmillan.

Guardino, C., Hall, K. W., Largo-Wight, E., \& Hubbuch, C. (2019). Teacher and student perceptions of an outdoor classroom. Journal of Outdoor and Environmental Education, 22(2), 113-126. https:// doi.org/10.1007/s42322-019-00033-7

Johnson, R. B. (1997). Examining the validity structure of qualitative research. Education, 118(2), 282-292.

Jordet, A. N. (2010). Klasserommet utenfor: tilpasset opplaring $i$ et utvidet laringsrom. Cappelen akademisk.

Lyngstad, I., \& Sæther, E. (2020). The concept of 'friluftsliv literacy'in relation to physical literacy in physical education pedagogies. Sport, Education and Society, 1-13. https://doi.org/10.1080/13573 322.2020.1762073.

Mannion, G., \& Lynch, J. (2016). The primacy of place in education in outdoor settings. In B. Humberstone, H. Prince, \& K. A. Henderson (Eds.), International Handbook of Outdoor Studies (pp. 85-94). Routledge.

Merriam, S. B. (2009). Qualitative Research. Jossey-Bass.

Murphy, M. C. (2020). Bronfenbrenner's bio-ecological model: A theoretical framework to explore the forest school approach? Journal of Outdoor and Environmental Education, 23(2), 191-205. https:// doi.org/10.1007/s42322-020-00056-5

Mølstad, C. E., Prøitz, T. S., \& Dieude, A. (2020). When assessment defines the content-understanding goals in between teachers and policy. The Curriculum Journal. https://doi.org/10.1002/curj.74

Nicol, R. (2003). Outdoor education: Research topic or universal value? Part three. Journal of Adventure Education \& Outdoor Learning, 3(1), 11-27. https://doi.org/10.1080/14729670385200211 
Ord, J., \& Leather, M. (2011). The substance beneath the labels of experiential learning: The importance of John Dewey for outdoor educators. Australian Journal of Outdoor Education, 15, 13-23. https:// doi.org/10.1007/BF03400924

Osberg, D., Biesta, G., \& Cilliers, P. (2008). From representation to emergence: Complexity's challenge to the epistemology of schooling. Educational Philosophy and Theory, 40(1), 213-227. https://doi. org/10.1111/j.1469-5812.2007.00407.x

Otte, C. R., Bølling, M., Stevenson, M. P., Ejbye-Ernst, N., Nielsen, G., \& Bentsen, P. (2019). Education outside the classroom increases children's reading performance: Results from a one-year quasiexperimental study. International Journal of Educational Research, 94, 42-51. https://doi.org/10. 1016/j.ijer.2019.01.009

Pellegrino, J., \& Hilton, M. (2012). Education for Life and Work: Developing Transferable Knowledge and Skills in the 21st Century. The National Academies Press.

Quay, J., \& Seaman, J. (2013). John Dewey and education outdoors: Making sense of the "educational situation" through more than a century of progressive reforms. Sense Publishers.

Resaland, G. K., Aadland, E., Moe, V. F., Aadland, K. N., Skrede, T., Stavnsbo, M., Suominen, L., Steene-Johannessen, J., Glosvik, Ø., Andersen, J. R., Kvalheim, O. M., Engelsrud, G., Andersen, L. B., Holme, I. M., Ommundsen, Y., Kriemler, S., van Mechelen, W., McKay, H. A., Ekelund, U., \& Anderssen, S. A. (2016). Effects of physical activity on schoolchildren's academic performance: The Active Smarter Kids (ASK) cluster-randomized controlled trial. Preventive Medicine, 91, 322328. https://doi.org/10.1016/j.ypmed.2016.09.005

Rickinson, M., Dillon, J., Teamey, K., Morris, M., Young, M., Sanders, D., \& Benefield, P. (2004). A review of research on outdoor learning. National Foundation for Educational Research and King's College London ; Field Studies Council.

Roberts, J. W. (2012). Beyond learning by doing: theoretical currents in experiential education. Routledge.

Rorty, R. (1998). Rosseau's education experiments. In R. Rorty (Ed.), Philosophies of education (pp. 238-254). Routledge.

Schneller, M. B., Schipperijn, J., Nielsen, G., \& Bentsen, P. (2017). Children's physical activity during a segmented school week: Results from a quasi-experimental education outside the classroom intervention. International Journal of Behavioral Nutrition and Physical Activity, 14(1), 80. https://doi. org/10.1186/s12966-017-0534-7

The Norwegian Directorate for Education and Training. (2020). Fagfornyelsen: Nye lareplaner. Retrieved April 7, 2021, from https:/www.udir.no/laring-og-trivsel/lareplanverket/fagfornyelsen/.

Waite, S., Bølling, M., \& Bentsen, P. (2016). Comparing apples and pears? A conceptual framework for understanding forms of outdoor learning through comparison of English Forest Schools and Danish udeskole. Environmental Education Research, 22(6), 868-892. https://doi.org/10.1080/13504622. 2015.1075193

Warner, R., Meerts-Brandsma, L., \& Rose, J. (2020). Neoliberal ideologies in outdoor adventure education: Barriers to social justice and strategies for change. Journal of Park and Recreation Administration, 38(3), 77-92. https://doi.org/10.18666/JPRA-2019-9609

Winje, Ø., \& Løndal, K. (2020). Bringing deep learning to the surface. Nordic Journal of Comparative and International Education (NJCIE), 4(2), 25-41. https://doi.org/10.7577/njcie.3798.

Yin, R. K. (2008). Case study research: Design and method. Sage.

Publisher's note Springer Nature remains neutral with regard to jurisdictional claims in published maps and institutional affiliations.

Øystein Winje is PhD-candidate in Physical Education at Oslo Metropolitan University, Norway. His research focus is uteskole [outdoor school] and deep Learning in primary and secondary education. He has previous experience as a teacher in primary school and is currently involved in education of Physical Education teachers.

Knut Løndal is professor in Physical Education at Oslo Metropolitan University, Norway. His expertise is on Physical Education in school and on children's physical activity and play in childcare institutions. He has previous experience as a teacher in primary and secondary school and is currently involved in education of Physical Education teachers. 